\title{
Examination of Pervasiveness of Elevated Serum Uric Acid Level and Microalbuminuria in Prehypertension
}

\author{
Sunjay Pathak ${ }^{\circledR 1}$, Mahipal Singh Puri ${ }^{\circledR 2}$ \\ ${ }^{1}$ Assistant Professor, Department of General Medicine, Varun Arjun Medical College and Rohilkhand Hospital, Banthra, Shahjehanpur, Uttar Pradesh, India, \\ ${ }^{2}$ Department of Medicine, Rajshree Medical Research Institute, Bareilly, Uttar Pradesh, India.
}

\section{Abstract}

Background: The relationship between uric acid and microalbuminuria in healthy adults without other cardiovascular risk factors may help to clarify the role of uric acid in cardiovascular disease. In this study, we examined that elevated serum uric acid level was associated with microalbuminuria. Subjects and Methods: Study was done on both male and female prehypertensive patients of age more than 18 years and less than 60, admitted in wards and attending OPD. Controls were normotensive patients admitted in wards who were matched for age, sex and confounding factors. Results: Hyperuricemia was found in 53 (15.14\%) patients with prehypertension compared to 32 (9.14\%) patients with normal BP. Thus hyperuricemia was seen in patients of prehypertension which was highly significant as $\mathrm{P}<0.001$. Conclusion: In conclusion we found that microalbuminuria and hyperuricemia are significantly more prevalent among prehypertensive subjects as compared to normotensive subjects.

Keywords: Serum Uric Acid, Microalbuminuria, Prehypertension

Corresponding Author: Mahipal Singh Puri, Department of Medicine, Rajshree Medical Research Institute, Bareilly, Uttar Pradesh, India. E-mail:mp3023@yahoo.com

Received: 12 March 2020

\section{Introduction}

Hyperuricemia is an independent risk factor for kidney dysfunction in pre-hypertensive patients. Various findings suggest that uric acid is an inflammatory factor and may have a role in endothelial dysfunction and act as a mediator of diabetic nephropathy. On the other hand, albuminuria is considered as the predicator of early stages of diabetic nephropathy. We investigated the association between hyperuricemia and albuminuria in patients with pre-hypertension. So it is a designation to identify individuals at high risk developing cardiovascular complications. So that both patients \& clinicians are alerted to this risk \& encouraged to intervene \& prevent or delay the disease from developing. According to JNC VII classification (American Medical Association), Prehypertension is defined as either systolic BP 120-139 $\mathrm{mm} \mathrm{Hg} \mathrm{\& /or} \mathrm{diastolic} \mathrm{BP}$ $80-89 \mathrm{mmHg}$ based on " 2 or more properly measured seated BP readings on each of 2 or more office visits." ${ }^{[1]}$ In humans, the upper end of the normal range is $360 \mu \mathrm{mol} / \mathrm{L}(6 \mathrm{mg} / \mathrm{dL})$ for women and $400 \mu \mathrm{mol} / \mathrm{L}(7 \mathrm{mg} / \mathrm{dL})$ for men. ${ }^{[1]}$ Recent experimental \& clinical studies have implicated increased serum uric acid levels in prehypertension. An elevation in uric acid may be critical initiator of renal mechanism leading to development of essential hypertension via both its ability to cause endothelial dysfunction \& rennin activation and by causing intrarenal lesion that mediate the development of salt sensitivity. ${ }^{[2-6]}$

Microalbuminuria is associated with an increased risk of cardiovascular morbidity in patients with diabetes, ${ }^{[7,8]}$ hypertension, ${ }^{[9-11]}$ and in the general population. ${ }^{[12-14]}$ The amount of urinary albumin excretion is considered to be a reflection of generalized endothelial dysfunction associated with a variety of risk factors. ${ }^{[15]}$ Therefore, microalbuminuria is a useful biological marker for the identification of people who are at high risk for cardiovascular events and who require more intensive therapy. ${ }^{[16]}$ Furthermore high uric acid level have been associated with increase generation of free radicals \& oxidative stress, which may abolish endothelial cells \& vascular smooth muscle cells thus leading to hypertension. ${ }^{[17]}$ The relationship between uric acid and microalbuminuria in healthy adults without other cardiovascular risk factors may help to clarify the role of uric acid in cardiovascular disease. In this study, we examined that elevated serum uric acid level was associated with microalbuminuria among nondiabetic and nonhypertensive subjects without a history of cardiovascular disease or renal dysfunction. We were 
particularly interested in subjects with prehypertension. The rela- tionship between blood pressure and blood pressurerelated morbidity is continuous over the whole range of blood pressure. If hyperuricemia has an independent role in target organ damage among hypertensive subjects, perhaps in combination with prehypertension, it might also be associated with microalbuminuria. ${ }^{[18-20]}$

\section{Subjects and Methods}

This study was carried out in the Department of Medicine, VarunArjun Medical College and Rohilkhand Hospital Banthra, Shahjehanpur from March 2016 to May 2017, over the period of 15 months.

Study was done on both male and female prehypertensive patients of age more than 18 years and less than 60, admitted in wards and attending OPD under the Department of Medicine, VarunArjun Medical College and Rohilkhand Hospital Banthra, Shahjehanpur. Controls were normotensive patients admitted in wards who were matched for age, sex and confounding factors.

Study Design: It was an observational cross- sectional comparative hospital based study.

Sample Size: A total of 350 subjects comprising of 175 prehypertensive and 175 normotensive subjects

\section{Inclusion Criteria}

Non-diabetic,non-hypertensive subjects with their BP in prehypertensive range were included in the study. For control group normotensive subjects were taken.

\section{Exclusion Criteria}

Patients with overt nephropathy as evidenced by positive dipstick test for albumin in urine or spot Albumin Creatinine ratio $>300 \mathrm{mg} / \mathrm{gm}$ of creatinine, conditions leading to Albuminuria like pregnancy, urinary tract infection, congestive cardiac failure, acute stressful illness like fever due to any cause, myeloproliferative or lymphoproliferative disorders or $\mathrm{H} / \mathrm{O}$ taking medications which may increase the serum uric acid levels like diuretics, ethambutol, pyrazinamide, levodopa, nicotinic acid cyclosporine \& alcohol, ischemic changes in ECG and regional wall motion abnormality in echocardiography.

\section{Statistical analysis}

The data were analyzed using Excel 2003, R 2.8.0 Statistical Package for the Social Sciences (SPSS) for Windows Version 16.0 (SPSS Inc; Chicago, IL, USA). Association between hypertension and microalbuminuria was tested by Chi-square test. Odds ratio was also calculated. Comparison of mean of continuous data between stages different group of urinary ACR level was tested by ANOVA test. A P-value of $<0.05$ (two-tailed) was used to establish statistical significance.

\section{Results}

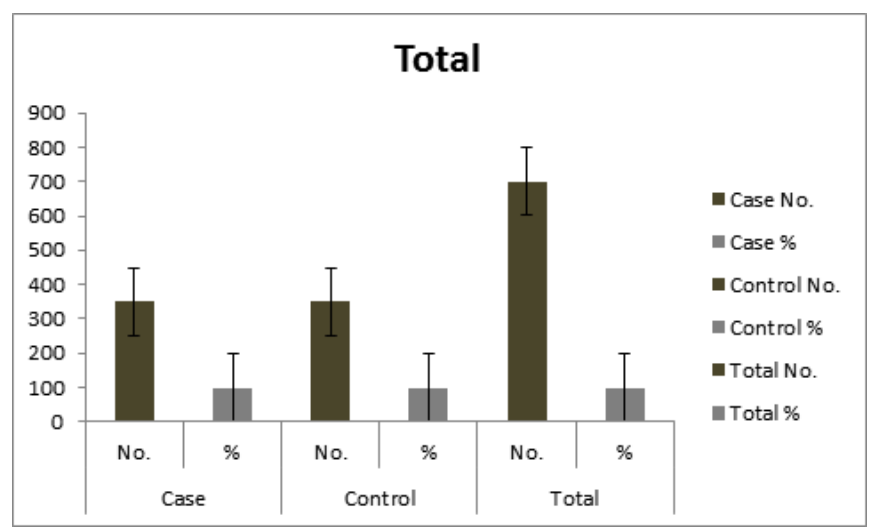

Figure 1: Total number of cases.

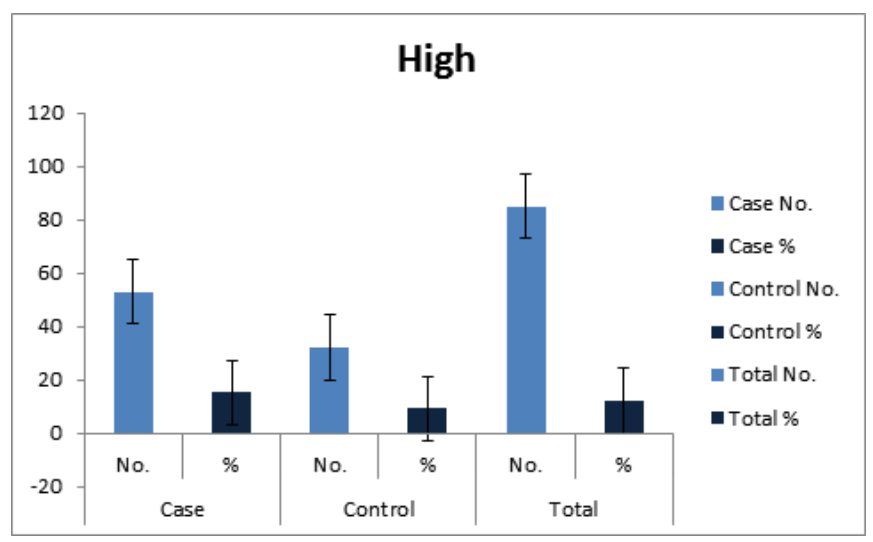

Figure 2: High Serum uric acid Amongst Study Population

Hyperuricemia was found in $53(15.14 \%)$ patients with prehypertension compared to $32(9.14 \%)$ patients with normal BP. Thus hyperuricemia was seen in patients of prehypertension which was highly significant as $\mathrm{P}<0.001$. Figure $1-4$ showing the Serumuric acid Amongst Study Population.

Table 1 shows the comparison of mean value of demographic, clinical, and biochemical characteristics to different level of ACR group. Serum level of total cholesterol (P-value 0.179), TG (P-value 0.520$)$, and LDL-C (P-value 0.079 ) were found to be insignificantly increased with the increased level of urinary ACR. However, serum level of HDL-C (P-value 0.015) was found to be significantly decreased with the increased level of urinary ACR. Similarly, serum level of uric acid (P-value 0.47) and creatinine (P-value $<0.001$ ) were found to be significantly increased with the increased level of urinary ACR. With the increases of age (P-value $<0.001$ ), the level of urinary 


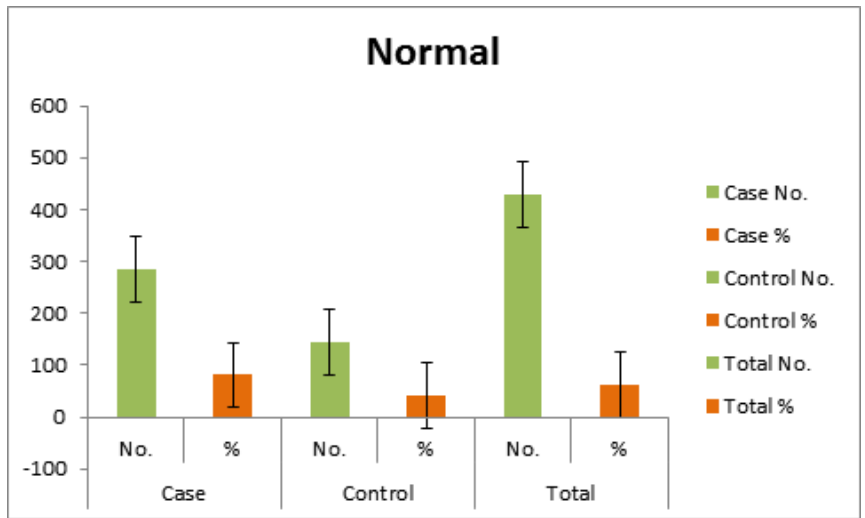

Figure 3: Normal Serum uric acid Amongst Study Population

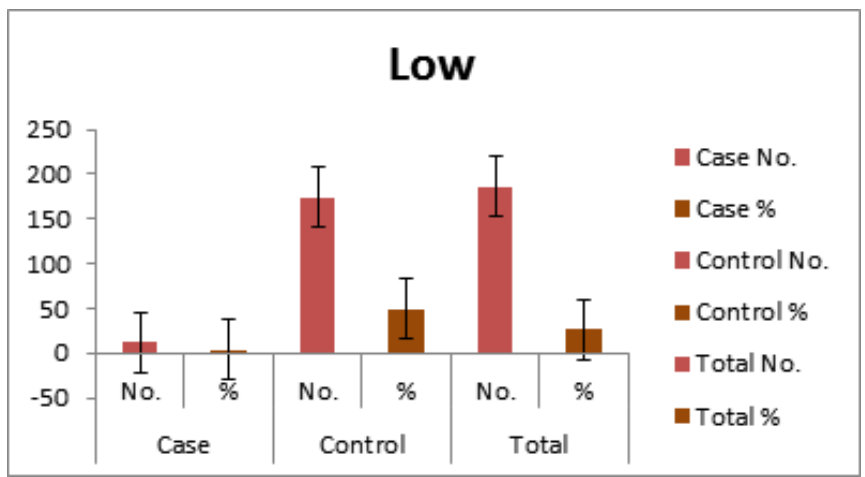

Figure 4: Low Serum uric acid Amongst Study Population

ACR was also increased. Systolic blood pressure (P-value $<0.001$ ) and diastolic blood pressure (P-value $<0.001)$ were significantly increased with the level of urinary ACR whereas eGFR (P-value $<0.001$ ) level was significantly decreased with increased level of urinary ACR.

\section{Discussion}

Increased serum uric acid level was an independent factor for microalbuminuria in the prehyperten- sive group. It is well known that microalbuminuria is asso- ciated with an increased risk for cardiovascular disease and might be an easily detectable marker for generalized vascular dysfunction. Our findings suggest that serum uric acid level can be a strong predictor of cardiovascular disease when combined with elevated blood pressure (even mildly ele- vated). Endothelial dysfunction may be a possible pathway linking uric acid and cardiovascular disease. ${ }^{[21]}$
Table 1: Demographic, clinical, and renal characteristics of participants with different level of ACRable

\begin{tabular}{|c|c|c|c|c|}
\hline Character & $\begin{array}{l}\text { Normoalb } \\
(\mathrm{ACR}<3.4\end{array}$ & $\begin{array}{l}\text { Microalbu } \\
(\mathrm{ACR}<3.4 \\
\text { and } \\
<33.9 \\
\mathrm{mg} / \mathrm{mmol})\end{array}$ & $\begin{array}{l}\text { Microalbu } \\
(\mathrm{ACR}<33 \text {. }\end{array}$ & P-Value \\
\hline Age,Y & $\begin{array}{l}43.15 \pm \\
11.26\end{array}$ & $\begin{array}{l}45.73 \pm \\
11.31\end{array}$ & $\begin{array}{l}55.34 \pm \\
7.99\end{array}$ & 0.001 \\
\hline $\begin{array}{l}\text { No.of } \\
\text { Subject } \\
350\end{array}$ & $196(56)$ & $\begin{array}{l}109 \\
(31.14)\end{array}$ & $\begin{array}{l}45 \\
(12.85)\end{array}$ & \\
\hline $\begin{array}{l}\text { Body } \\
\text { mass } \\
\text { Index, } \\
\mathrm{kg} / \mathrm{m} 2\end{array}$ & $\begin{array}{l}23.9 \pm \\
3.61\end{array}$ & $\begin{array}{l}24.8 \pm \\
3.79\end{array}$ & $\begin{array}{l}24.91 \pm \\
2.26\end{array}$ & 0.09 \\
\hline $\begin{array}{l}\text { Systolic } \\
\text { arterial } \\
\text { pressure } \\
\mathrm{mm} \mathrm{Hg}\end{array}$ & $\begin{array}{l}125.78 \pm \\
17.99\end{array}$ & $\begin{array}{l}136.56 \\
\pm 19.27\end{array}$ & $\begin{array}{l}156 \quad \pm \\
20.07\end{array}$ & 0.000 \\
\hline $\begin{array}{l}\text { Diastolic } \\
\text { arterial } \\
\text { pressure } \\
\mathrm{mm} \mathrm{Hg}\end{array}$ & $\begin{array}{l}82.9 \\
13.48\end{array}$ & $\begin{array}{l}89.87 \pm \\
13.5\end{array}$ & $\begin{array}{l}97.95 \pm \\
10.48\end{array}$ & 0.000 \\
\hline $\begin{array}{l}\text { Serum } \\
\text { Crea- } \\
\text { tinine, } \\
\mathrm{mg} / \mathrm{dL}\end{array}$ & $\begin{array}{l}80.9 \pm \\
13.49\end{array}$ & $\begin{array}{l}107.15 \\
\pm 24.29\end{array}$ & $\begin{array}{l}130 \pm \\
31.59\end{array}$ & 0.001 \\
\hline $\begin{array}{l}\text { Serum } \\
\text { uric acid, } \\
\mathrm{mg} / \mathrm{dL}\end{array}$ & $\begin{array}{l}244.08 \pm \\
104.36\end{array}$ & $\begin{array}{l}273.16 \\
\pm \\
122.60\end{array}$ & $\begin{array}{l}308.47 \pm \\
98.24\end{array}$ & 0.047 \\
\hline $\begin{array}{l}\text { Total } \\
\text { Choles- } \\
\text { terol, } \\
\mathrm{mg} / \mathrm{dL}\end{array}$ & $\begin{array}{l}5.83 \pm \\
1.86\end{array}$ & $\begin{array}{l}5.99 \pm \\
2.03\end{array}$ & $\begin{array}{l}6.25 \pm \\
2.03\end{array}$ & 0.179 \\
\hline $\begin{array}{l}\text { HDL } \\
\text { Choles- } \\
\text { terol, } \\
\mathrm{mg} / \mathrm{dL}\end{array}$ & $\begin{array}{l}2.15 \pm \\
0.29\end{array}$ & $\begin{array}{l}2.07 \pm \\
0.31\end{array}$ & $\begin{array}{l}0.98 \quad \pm \\
0.31\end{array}$ & 0.015 \\
\hline $\begin{array}{l}\text { LDL } \\
\text { Choles- } \\
\text { terol, } \\
\mathrm{mg} / \mathrm{dL}\end{array}$ & $\begin{array}{l}3.94 \pm \\
0.91\end{array}$ & $\begin{array}{l}4.16 \pm \\
2.058\end{array}$ & $\begin{array}{l}4.47 \quad \pm \\
0.99\end{array}$ & 0.079 \\
\hline $\begin{array}{l}\text { Triglycend } \\
\mathrm{mg} / \mathrm{dL}\end{array}$ & $\begin{array}{l}2.650 \pm \\
0.76\end{array}$ & $\begin{array}{l}2.8 \quad \pm \\
0.81\end{array}$ & $\begin{array}{l}2.91 \quad \pm \\
0.93\end{array}$ & 0.520 \\
\hline $\begin{array}{l}\text { Glomerula } \\
\text { filtration } \\
\text { rate, } \\
\mathrm{mL} / \mathrm{min} \\
\text { per } 1.73 \\
\mathrm{~m}^{2}\end{array}$ & $\begin{array}{l}95.7 \pm \\
27.26\end{array}$ & $\begin{array}{l}83.64 \pm \\
20.97\end{array}$ & $\begin{array}{l}73.79 \pm \\
18.8\end{array}$ & 0.000 \\
\hline
\end{tabular}


Although several studies have previously shown the association between hyperuricemia and microalbuminuria in hypertensive patients, ${ }^{[22,23]}$ its relationship in subjects without hypertension is unknown. To our knowledge, the present study is the first research to demonstrate that serum uric acid level is associated with an increased risk for microalbumin- uria in subjects with prehypertension.

It is unknown whether increased uric acid level and high blood pressure have synergistic effects on microalbuminuria or whether serum uric acid level is another marker of target organ damage by high blood pressure. However, in the normotensive group, there was no difference in serum uric acid level according to the presence or absence of microal- buminuria. Furthermore, serum uric acid level still had an independent correlation with microalbuminuria after adjustment for other cardiovascular risk factors in the prehy- pertensive group. These findings suggest that increased uric acid level in the prehypertensive group may have a patholog-ical role in target organ damage.

According to this study amongst $68 \%$ age and sex matched cases and controls, microalbuminuria (quantitative) was found in $51(17 \%)$ patients with prehypertension compared to $31(10.33 \%)$ patients with normal BP which was highly significant as $\mathrm{p}<0.05$ Mean urine albumin creatinine ratio (UACR) was $26.78+59.24$ in cases compared to $7.55+19.85$ in controls with $\mathrm{p}<0.001$ which was highly significant.

Several mechanisms have been proposed to explain a possible causal relationship. ${ }^{[24,25]}$ It has been shown previously that hyperuricemia induced endothelial dysfunction, glomerular hypertension, and renal hypertrophy, even in conditions of mild hypertension in experimental rat models. ${ }^{[21,26-30]}$ Our human data consistently showed that the serum uric acid level in prehypertensive subjects was associated with microalbuminuria and that GFR correlated positively with ACR in this setting. Prehypertensive subjects with microalbuminuria had higher GFR levels than those with normoalbuminuria (86 versus $\left.83 \mathrm{~mL} / \mathrm{min} / 1.73 \mathrm{~m}^{2} ; \mathrm{P}=0.002\right)^{[10,12]}$ Therefore, we presumed that increased serum uric acid level combined with prehypertension might cause an endothelial dysfunction and result in glomerular hypertension, which would induce microalbuminuria and hyperfiltration. It is still unclear whether microalbuminuria in this setting can act as an early marker for renal progression.

\section{Conclusion}

In conclusion we found that microalbuminuria and hyperuricemia are significantly more prevalent among prehypertensive subjects as compared to normotensive subjects so that measurement of these parameters can serve as low cost, accurate $\&$ reliable clinical tool to identify prehypertensive patient at higher risk of subclinical target organ damage. microalbu- minuria and hyperuricemia was more prevalent in prehypertensive individuals without a history of cardiovascular disease or decreased renal function as compared to normotensive individuals. Although we are unable to determine whether hyperuricemia has a causative effect, these findings suggest that hyperuricemia combined with prehypertension might be associated with an increased risk of cardiovascular disease.

\section{References}

1. Chizyński K, Rózycka M, Hyperuricemia. Blood Pressure Measurement Guidelines for Physical Therapists. Cardiopulm Phys Ther J. 2011;22(2):5-12.

2. Khosla UM, Zharikov S, Finch JL, Nakagawa T, Roncal C, $\mathrm{Mu} \mathrm{W}$, et al. Hyperuricemia induces endothelial dysfunction. Kidney Int. 2005;67(5):1739-1742. Available from: https://dx. doi.org/10.1111/j.1523-1755.2005.00273.x.

3. Mazzali M, Hughes J, Kim YG, Jefferson JA, Kang DH, Gordon KL, et al. Elevated Uric Acid Increases Blood Pressure in the Rat by a Novel Crystal-Independent Mechanism. Hypertension. 2001;38(5):1101-1106. Available from: https: //dx.doi.org/10.1161/hy1101.092839.

4. Nakagawa T, Mazzali M, Kang DH, Kanellis J, Watanabe S, Sanchez-Lozada LG, et al. Hyperuricemia Causes Glomerular Hypertrophy in the Rat. Am J Nephrol. 2003;23(1):2-7. Available from: https://dx.doi.org/10.1159/000066303.

5. Mazzali M, Kanellis J, Han L, Feng L, Xia YY, Chen Q. Hyperuricemia induces a primary renal arteriopathy in rats by a blood pressure-independent mechanism. Am J Physiol Renal Physiol. 2002;282(6):991-997.

6. Sánchez-Lozada LG, Tapia E, Avila-Casado C, Soto V, Franco M, Santamaría J, et al. Mild hyperuricemia induces glomerular hypertension in normal rats. Am J Physiol-Renal. 2002;283(5):F1105-F1110. Available from: https://dx.doi.org/ 10.1152/ajprenal.00170.2002.

7. Dinneen SF, Gerstein HC. The association of microalbuminuria and mortality in non-insulin-dependent diabetes mellitus. A systematic overview of the literature. Arch Intern Med. 1997; 157:1413-1418.

8. Messent JWC, Elliott TG, Hill RD, Jarrett RJ, Keen H, Viberti G. Prognostic significance of microalbuminuria in insulindependent diabetes mellitus: A twenty-three year follow-up study. Kidney Int. 1992;41(4):836-839. Available from: https: //dx.doi.org/10.1038/ki.1992.128.

9. Verdecchia P, Reboldi GP. Hypertension and microalbuminuria: the new detrimental duo. Blood Pressure. 2004;13(4):198-211. Available from: https://dx.doi.org/10. 1080/08037050410016456.

10. Bianchi S, Bigazzi R, Campese VM. Microalbuminuria in essential hypertension: Significance, pathophysiology, and therapeutic implications. Am J Kidney Dis. 1999;34(6):973-995. Available from: https://dx.doi.org/10. 1016/s0272-6386(99)70002-8.

11. Bigazzi R, Bianchi S, Baldari D, Campese VM. Microalbuminuria predicts cardiovascular events and renal insufficiency in patients with essential hypertension. J Hypertens. 
1998;16(9):1325-1333. Available from: https://dx.doi.org/10. 1097/00004872-199816090-00014.

12. Hillege HL, Janssen WMT, Bak AAA, Diercks GFH, Grobbee DE, Crijns HJGM, et al. Microalbuminuria is common, also in a nondiabetic, nonhypertensive population, and an independent indicator of cardiovascular risk factors and cardiovascular morbidity. J Internal Med. 2001;249(6):519-526. Available from: https://dx.doi.org/10.1046/j.1365-2796.2001.00833.x.

13. Hillege HL, Fidler V, Diercks GFH, van Gilst WH, de Zeeuw D, van Veldhuisen DJ, et al. Urinary Albumin Excretion Predicts Cardiovascular and Noncardiovascular Mortality in General Population. Circulation. 2002;106(14):1777-1782. Available from: https://dx.doi.org/10.1161/01.cir.0000031732.78052.81.

14. Klausen K, Borch-Johnsen K, Feldt-Rasmussen B, Jensen $\mathrm{G}$, Clausen P, Scharling $\mathrm{H}$, et al. Very Low Levels of Microalbuminuria Are Associated With Increased Risk of Coronary Heart Disease and Death Independently of Renal Function, Hypertension, and Diabetes. Circulation. 2004;110(1):32-35. Available from: https://dx.doi.org/10. 1161/01.cir.0000133312.96477.48.

15. Albuminuria D. Not only a cardiovascular/renal risk marker, but also a target for treatment? Kidney Int. 2004;66:2-6.

16. Yuyun MF, Adler AI, Wareham NJ. What is the evidence that microalbuminuria is a predictor of cardiovascular disease events? Curr Opin Nephrol Hypertens. 2005;14(3):271276. Available from: https://dx.doi.org/10.1097/01.mnh. 0000165895.90748.3b.

17. Rodillasala E, Lahiguera FP, Muñoz J, Enguita CG, Amparomiralles U, Moral D. Association between serum uric acid, metabolic syndrome and microalbuminuria in previously untreated essential hypertensive patients. Medicina clínica. 2009;132(1):1-6.

18. Knight EL, Kramer HM, Curhan GC. High-normal blood pressure and microalbuminuria. Am J Kidney Dis. 2003;41(3):588595. Available from: https://dx.doi.org/10.1053/ajkd.2003. 50120.

19. Vasan RS, Larson MG, Leip EP, Evans JC, O’Donnell CJ, Kannel WB, et al. Impact of High-Normal Blood Pressure on the Risk of Cardiovascular Disease. N Eng J Med. 2001;345(18):1291-1297. Available from: https://dx.doi.org/ 10.1056/nejmoa003417.

20. Svetkey LP. Management of Prehypertension. Hypertens. 2005;45(6):1056-1061. Available from: https://dx.doi.org/10. 1161/01.hyp.0000167152.98618.4b.

21. Khosla UM, Zharikov S, Finch JL, Nakagawa T, Roncal C, $\mathrm{Mu} \mathrm{W}$, et al. Hyperuricemia induces endothelial dysfunction. Kidney Int. 2005;67(5):1739-1742. Available from: https://dx. doi.org/10.1111/j.1523-1755.2005.00273.x.

22. Viazzi F, Parodi D, Leoncini G, Parodi A, Falqui V, Ratto E, et al. Serum Uric Acid and Target Organ Damage in Primary Hypertension. Hypertension. 2005;45(5):991996. Available from: https://dx.doi.org/10.1161/01.hyp. 0000161184.10873.ea.
23. Mattei P, Arzilli F, Giovannetti R, Penno G, Arrighi P, Taddei $\mathrm{S}$, et al. Microalbuminuria and renal haemodynamics in essential hypertension. Eur J Clin Invest. 1997;27(9):755-760. Available from: https://dx.doi.org/10.1046/j.1365-2362.1997. 1840733.x.

24. Johnson RJ, Kang DH, Feig D, Kivlighn S, Kanellis J, Watanabe $\mathrm{S}$, et al. Is There a Pathogenetic Role for Uric Acid in Hypertension and Cardiovascular and Renal Disease? Hypertension. 2003;41(6):1183-1190. Available from: https: //dx.doi.org/10.1161/01.hyp.0000069700.62727.c5.

25. Johnson RJ, Segal MS, Srinivas T, Ejaz A, Mu W, Roncal C, et al. Essential Hypertension, Progressive Renal Disease, and Uric Acid: A Pathogenetic Link?: Table 1. J Am Soc Nephrol. 2005;16(7):1909-1919. Available from: https://dx.doi.org/10. 1681/asn.2005010063.

26. Mazzali M, Hughes J, Kim YG, Jefferson JA, Kang DH, Gordon KL, et al. Elevated Uric Acid Increases Blood Pressure in the Rat by a Novel Crystal-Independent Mechanism. Hypertension. 2001;38(5):1101-1106. Available from: https: //dx.doi.org/10.1161/hy1101.092839.

27. Nakagawa T, Mazzali M, Kang DH, Kanellis J, Watanabe S, Sanchez-Lozada LG, et al. Hyperuricemia Causes Glomerular Hypertrophy in the Rat. Am J Nephrol. 2003;23(1):2-7. Available from: https://dx.doi.org/10.1159/000066303.

28. Mazzali M, Kanellis J, Han L, Feng L, Xia YY, Chen Q. Hyperuricemia induces a primary renal arteriolopathy in rats by a blood pressure-independent mechanism. Am J Physiol Renal Physiol. 2002;282:991-997.

29. Sánchez-Lozada LG, Tapia E, Avila-Casado C, Soto V, Franco M, Santamaría J, et al. Mild hyperuricemia induces glomerular hypertension in normal rats. Am J Physiol-Renal. 2002;283(5):F1105-F1110. Available from: https://dx.doi.org/ 10.1152/ajprenal.00170.2002.

30. Kang DH, Han L, Ouyang X, Kahn AM, Kanellis J, Li P. Uric acid causes vascular smooth muscle cell proliferation by entering cells via a functional urate trans- porter. Am J Nephrol. 2005;25:425-433.

Copyright: (C) the author(s), 2020. It is an open-access article distributed under the terms of the Creative Commons Attribution License (CC BY 4.0), which permits authors to retain ownership of the copyright for their content, and allow anyone to download, reuse, reprint, modify, distribute and/or copy the content as long as the original authors and source are cited.

How to cite this article: Pathak S, Puri MS. Examination of Pervasiveness of Elevated Serum Uric Acid Level and Microalbuminuria in Prehypertension. Acad. J Med. 2020;3(1): 27-31.

DOI: dx.doi.org/10.47008/ajm.2020.3.1.7

Source of Support: Nil, Conflict of Interest: None declared. 